Tropical Journal of Pharmaceutical Research August 2020; 19 (8): 1625-1630

ISSN: $1596-5996$ (print); 1596-9827 (electronic)

(C) Pharmacotherapy Group, Faculty of Pharmacy, University of Benin, Benin City, 300001 Nigeria.

\title{
Quinolinol-platinum (II) complex suppresses survival and invasion of laryngeal cancer cells via targeting YES- associated protein expression
}

\author{
Baotong $\mathrm{Xie}^{1}$, Tao $\mathrm{Li}^{2 *}$ \\ ${ }^{1}$ Department of Otolaryngology, ${ }^{2}$ Department of Ophthalmology, Lvliang People's Hospital, Lvliang Hospital Affiliated of Shanxi \\ Medical University, Lvliang 033000, Shanxi Province, China
}

*For correspondence: Email: KinsleyWeisseuu@yahoo.com

Sent for review: 18 January 2020

Revised accepted: 22 July 2020

\begin{abstract}
Purpose: To investigate the anti-proliferative potential of quinolinol-platinum (II) complex $\{$ QN-Pt (II)\} in laryngeal cancer cells.

Methods: The inhibitory potential of QN-Pt (II) on the proliferation of laryngeal cancer cells was determined using 2H-tetrazolium, 2-(4,5-dimethyl-2-thiazolyl)-3,5-diphenyl bromide (MTT) and colony formation assays. Inhibition of cell migration was determined using wound-healing assay, while changes in LC3-II and p62 expressions were assessed by western blotting.

Results: QN-Pt (II) inhibited the viability of TU212 and M4e laryngeal cancer cells in the concentration range of 2 to $10 \mu \mathrm{M}(\mathrm{p}<0.05)$. Moreover, it suppressed the colony formation potential and migration of TU212 and M4e cells. The QN-Pt (II) treatment increased the proportion of TU212 and M4e cells in G1/G0 phase of the cell cycle, but decreased the cell proportion in $S$ and G2/M phase $(p<0.05)$. Treatment with $10 \mu \mathrm{M}$ QN-Pt (II) increased the expression of LC3-II, but downregulated P62 expression in TU212 and M4e cells. The expression of Yes-associated protein was inhibited in TU212 and M4e cells on treatment with QN-Pt (II). However, transfection of YAP-cDNA into TU212 and M4e cells reversed the inhibitory effect of QN-Pt (II) on cell proliferation $(p<0.05)$. Moreover, YAP-cDNA transfection suppressed LC3II expression, inhibited YAP phosphorylation and promoted $P 62$ expression in QN-Pt (II)-treated TU212 and M4e cells ( $p<0.05)$.

Conclusion: QN-Pt (II) suppresses laryngeal cancer cell viability via arrest of cell cycle and activation of apoptosis. Moreover, QN-Pt (II) targets Yes-associated protein in laryngeal cancer cells. Thus, QN-Pt (II) is a potential therapeutic agent for laryngeal cancer.
\end{abstract}

Keywords: Laryngeal cancer, YAP-protein, Apoptosis, Phosphorylation, Therapeutic agent

\begin{abstract}
This is an Open Access article that uses a fund-ing model which does not charge readers or their institutions for access and distributed under the terms of the Creative Commons Attribution License (http://creativecommons.org/licenses/by/4.0) and the Budapest Open Access Initiative (http://www.budapestopenaccessinitiative.org/read), which permit unrestricted use, distribution, and reproduction in any medium, provided the original work is properly credited.

Tropical Journal of Pharmaceutical Research is indexed by Science Citation Index (SciSearch), Scopus, International Pharmaceutical Abstract, Chemical Abstracts, Embase, Index Copernicus, EBSCO, African Index Medicus, JournalSeek, Journal Citation Reports/Science Edition, Directory of Open Access Journals (DOAJ), African Journal Online, Bioline International, Open-J-Gate and Pharmacy Abstracts
\end{abstract}

\section{INTRODUCTION}

Laryngeal cancer comprises squamous cell carcinomas which originate from the skin of the larynx [1]. The prognosis of laryngeal cancer depends on its location in the larynx [2]. Laryngeal cancer is treated using chemotherapy, radiotherapy and surgery, either separately or as combination therapy [3]. The specific treatment for laryngeal cancer is decided based on its 
location, stage and category [4]. Severelyaffected laryngeal cancer patients are subjected to laryngectomy, in which the vocal cords are removed completely or partially [3]. Mortality due to laryngeal cancer has shown marked increases since 1990 [5]. Moreover, the average survival of patients with laryngeal cancer has also decreased, when compared to patients with other kinds of cancers [2]. Therefore, there is need for effective and novel therapeutic strategies for laryngeal cancer.

The treatment of various disorders/diseases using a variety of drugs is aimed at targeting different signaling pathways. Effective treatments result from accurate targeting signaling pathways by therapeutic molecules. The Hippo signaling pathways plays major role in maintaining the size of various organs, and in development of tumors [6]. A downstream factor of the Hippo pathway is Yes-associated protein (YAP) which is a cancerrelated oncogene [7]. It has been reported that YAP accelerates proliferation, suppresses apoptosis and enhances transformation of carcinoma cells [7]. The level of YAP protein is increased in carcinoma cells, including hepatic cancer cells [8].

Organic compounds linked to metal ions as metal-complexes have shown promising antitumor properties, but their use is limited by undesirable side effects [9]. This has led clinicians to replace the metal ion with organic compounds with known anti-cancer effects [10]. Novel complexes synthesized from metal ions by linkage to organic compounds have produced effective anti-tumor activities [11,12].

In the present study, the anti-proliferative potential of quinolinol-platinum (II) complex [QN$\mathrm{Pt}$ (II)] in laryngeal cancer cells was investigated for the first time.

\section{EXPERIMENTAL}

\section{Cell culture}

Cancer cell lines (TU212 and M4e) and normal cell line $(\mathrm{HBe})$ were obtained from the American Type Culture Collection (ATCC; Manassas, VA USA). The cell lines were cultured in RPMI-1640 medium (Gibco, Carlsbad, CA, USA) mixed with $10 \%$ fetal bovine serum (FBS; Gibco).

The medium contained penicillin $(100 \mathrm{U} / \mathrm{mL})$ and streptomycin $(100 \mathrm{mg} / \mathrm{mL})$. The cell culture was performed in an incubator in a $5 \% \mathrm{CO}_{2}$ atmosphere at $37^{\circ} \mathrm{C}$.

\section{Proliferation assay}

The TU212, M4e and HBe cells were seeded in 96-well plates at a density of $2 \times 10^{5}$ cells per well, and cultured for $24 \mathrm{~h}$. Then, fresh medium mixed with $1,2,4,6,8$ or $10 \mu \mathrm{M}$ QN-Pt (II) was added to the plates, and incubation was continued for $48 \mathrm{~h}$. Incubation with QN-Pt (II) was followed by addition of MTT solution $(5 \mathrm{mg} / \mathrm{mL}$ ) and further incubation for $4 \mathrm{~h}$ at $37^{\circ} \mathrm{C}$. The resultant formazan crystals in the plates were dissolved by adding $120 \mu \mathrm{L}$ of DMSO to each well of the plate. The optical density of each formazan solution was read in a Multimode Reader (Varioskan Flash; Thermo Fisher Scientific, Inc.) at $576 \mathrm{~nm}$. All assays were done in triplicate.

\section{Colony formation assay}

The colony forming potential of TU212, M4e and $\mathrm{HBe}$ cells was observed using optical light microscopy. The cells were seeded in 6-well plates at a density of $1 \times 10^{5}$ cells per well, and treated with 8 and $10 \mu \mathrm{M}$ QN-Pt (II) for $48 \mathrm{~h}$. Then, they were stained with crystal violet dye (Beyotime Institute) for $45 \mathrm{~min}$ at room temperature, and the stained cells were observed under optical light microscope (IX70; Olympus Corporation) for colony formation.

\section{Cell migration assay}

The TU212 and M4e cells were seeded in 60$\mathrm{mm}$ dishes at a density of $1 \times 10^{5}$ cells per dish, and were cultured to $100 \%$ confluence. A wound was created in the center of each dish by scratching the cellular monolayer with a $200-\mu \mathrm{L}$ pipette tip. The scratched cells were cleared by washing the dishes with PBS to remove any cell debris. This was followed by addition of serumfree medium. The cells were treated with 8 and $10 \mu \mathrm{M}$ QN-Pt (II), or normal saline (control) for 48 h. Wound healing was observed under an inverted microscope (Leica Microsystems, Wetzlar, Germany), and images were taken at x4 magnification using a digital camera.

\section{Determination of cell cycle progression}

The effect of QN-Pt (II) on cell cycle distribution in TU212 and M4e cells was determined using flow cytometry after treatment of the cells with 8 and $10 \mu \mathrm{M}$ QN-Pt (II) for $48 \mathrm{~h}$. Cells from each cell line were seeded in 6-well plates at a density of $2 \times 10^{5}$ cells per well in RPMI-1640 medium containing 8 and $10 \mu \mathrm{M}$ QN-Pt (II). Following treatment for $48 \mathrm{~h}$, the cells were washed in PBS after harvesting, and then fixed for $3 \mathrm{~h}$ in $70 \%$ ethyl alcohol. Thereafter, the cells were 
centrifuged for $5 \mathrm{~min}$, washed with PBS and resuspended in $320 \mu \mathrm{L}$ buffer containing RNase $(10 \mu \mathrm{L})$ and of $\mathrm{PI}(25 \mu \mathrm{L})$. The cells were incubated in the dark for $20 \mathrm{~min}$ at room temperature. Then, the cellular DNA content was analyzed in a flow cytometer (Beckman Coulter Inc.) for determination of cell cycle distribution.

\section{Transfection of cells}

The TU212 and M4e cells were grown in 6-well plates, each at a density of $2 \times 10^{5}$ cells per well, for $24 \mathrm{~h}$ at $37{ }^{\circ} \mathrm{C}$. Then, YAP-cDNA, small silencer (si)RNA or vector was transfected into the cells using lipofectamine $\AA 3000$ in accordance with the manufacturer's instructions. The sequence of YAP siRNA used was: forward: 5'-GGU GAU ACU AUC AAC CAA ATT-3'; and backward: 5'-UUU GGU UGA UAG UAU CAC CTT-3'. The cells were then separately treated with 8 or $10 \mu \mathrm{M}$ QN-Pt (II) for $48 \mathrm{~h}$.

\section{Western blot analysis}

Following QN-Pt (II) treatment, the TU212 and M4e cells were washed in ice-cold PBS and then lysed using modified RIPA buffer [50 mM Tris$\mathrm{HCl}$, pH 7.4 containing NP-40 (1.1\%), Nadeoxycholate $(0.3 \%)$, sodium chloride $(150 \mathrm{mM})$, $\mathrm{Na}_{3} \mathrm{VO}_{4}(1.1 \mathrm{mM})$ sodium fluoride $(1.1 \mathrm{mM})$ and protease inhibitors]. The lysate was centrifuged at $4^{\circ} \mathrm{C}$ for $25 \mathrm{~min}$ at $12,000 \mathrm{~g}$ and the protein content of the supernatant was estimated using BCA method. The proteins were resolved using electrophoresis on $12 \%$ SDS-PAGE, and subsequently transferred to PVDF membranes (EMD Millipore). The membranes were blocked by incubation with $5 \%$ skimmed milk at $37{ }^{\circ} \mathrm{C}$ for $2.5 \mathrm{~h}$. Then, the proteins were probed by overnight-incubation of the membranes with antiGAPDH, anti-LC3, anti-P62, anti-YAP and anti-pYAP primary antibodies at $4{ }^{\circ} \mathrm{C}$. Thereafter, the membranes were washed with PBS and subjected to incubation for $2 \mathrm{~h}$ with horseradish peroxidase-conjugated secondary antibody at room temperature. The signals were visualized

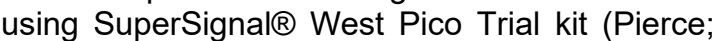
Thermo Fisher Scientific, Inc.), and were captured using ImageJ $1.43 \mathrm{U}$ system.

\section{Statistical analysis}

Data are expressed are mean \pm SEM $(n=3)$, and were compared amongst groups using GraphPad Prism (version 6.0; GraphPad Software, Inc., La Jolla, CA, USA). Data analysis was made with one-way ANOVA and Dunn's least significant difference tests. Differences amongst groups were taken as significant at $p<$ 0.05 .

\section{RESULTS}

\section{QN-Pt (II) decreased the viability of U212 and M4e cells}

Treatment of TU212 and M4e cancer cells with QN-Pt (II) in the concentration range of 1-10 $\mu \mathrm{M}$ suppressed their viability without affecting normal $\mathrm{HBe}$ cells (Figure $1 \mathrm{~A}$ ). The viabilities of TU212 and $\mathrm{M} 4 \mathrm{e}$ cells were reduced to 18 and 21, respectively on treatment with $10 \mu \mathrm{M} \mathrm{QN}-\mathrm{Pt}$ (II) for $48 \mathrm{~h}$. Increase in duration of QN-Pt (II) treatment from 24 to $48 \mathrm{~h}$ caused more decreases in viabilities of TU212 and M4e cells (Figures $1 \mathrm{~A}$ and $\mathrm{B}$ ). The colony-forming potential of TU212 and M4e cells were also reduced on treatment with QN-Pt (II), when compared to control (Figure $1 \mathrm{C}$ ).

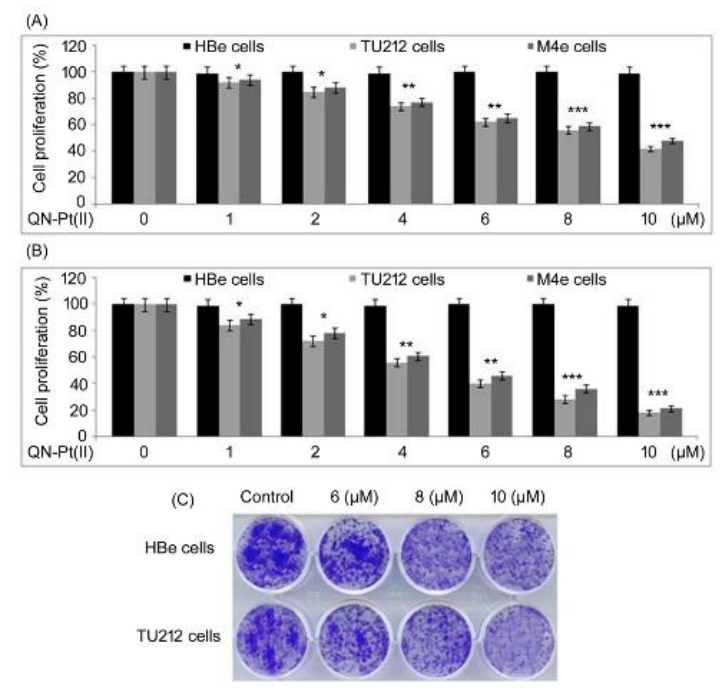

Figure 1: Effect of QN-Pt (II) on cell growth. A \& B: Cells treated with QN-Pt (II) for 24 and $48 \mathrm{~h}$ were subjected to measurement of changes in proliferation using MTT assay. C: Colony formation potential of TU212 and M4e cells treated with QN-Pt (II), as determined under an optical light microscope after staining with crystal violet. ${ }^{*} P<0.05,{ }^{* *} p<0.01,{ }^{* * *} p$ $<0.01$, vs. control cells

\section{QN-Pt (II) inhibited the migration of TU212 and M4e cells}

As shown in Figure 2, treatment with $10 \mu \mathrm{M} Q \mathrm{~N}$ $\mathrm{Pt}$ (II) for $48 \mathrm{~h}$ resulted in suppression of wound healing in TU212 and M4e cells. However, in control TU212 and M4e cells, the degrees of wound healing were 88 and $93 \%$, respectively, at $48 \mathrm{~h}$, relative to 5 and $8 \%$ wound healing in TU212 and M4e cells, respectively, on treatment with $10 \mu \mathrm{M}$ QN-Pt (II). 

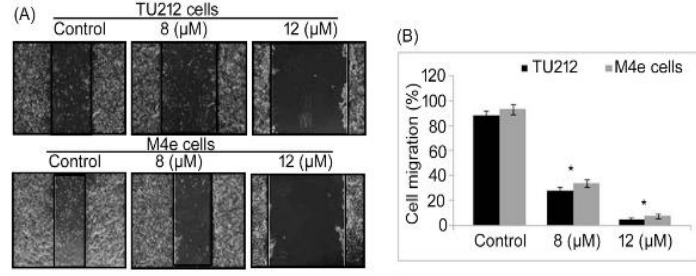

Figure 2: Effect of QN-Pt (II) migration of the cells. The TU212 and M4e cells were treated with $10 \mu \mathrm{M}$ QN-Pt (II) for $48 \mathrm{~h}$, and migration was determined using wound healing assay. ${ }^{*} P<0.05,{ }^{* *} p<0.01$ vs. control cells $(\mathrm{x} 200)$

QN-Pt (II) induced cell cycle arrest in TU212 and $M 4 e$ cells

Flow cytometric analysis of QN-Pt (II)-treated TU212 and M4e cells showed increased counts of cells in the G1/G0 phase of the cell cycle. The increase was concentration-dependent (Figures $3 \mathrm{~A}$ and $\mathrm{B}$ ). In TU212 cells, treatment with 8 and $10 \mu \mathrm{M}$ QN-Pt (II) increased G1/G0 phase cell count to $69.43 \pm 4.66$ and $74.37 \pm 4.82 \%$, respectively, relative to $47.76 \pm 2.19 \%$ in control. In M4e cells, QN-Pt (II) treatment at doses of 8 and $10 \mu \mathrm{M}$ increased $\mathrm{G} 1 / \mathrm{G} 0$ phase cells to 64.91 \pm 4.87 and $71.42 \pm 5.11 \%$, respectively, relative to $44.21 \pm 2.45 \%$ in control cells. In contrast, the populations of TU212 and M4e cells in S and G2/M phases were decreased by treatment with QN-Pt (II). The expression of p21 protein was enhanced in TU212 and M4e cells by QN-Pt (II) (Figure $3 \mathrm{C}$ ).

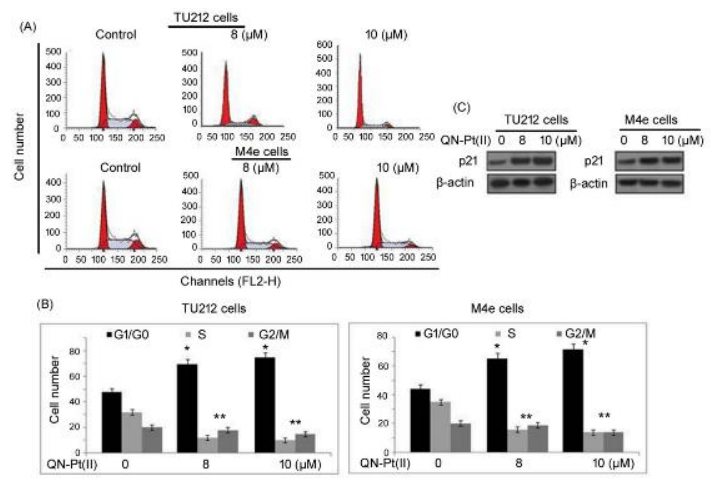

Figure 3: Effect of QN-Pt (II) on cell cycle distribution. A \& B: Cell cycle arrest in TU212 and M4e cells treated with 4,6 and $10 \mu \mathrm{M}$ QN-Pt (II) for $48 \mathrm{~h}$, followed by flow cytometric analysis after PI staining. C: Results of immunoblot assay for the protein expression of p21 in TU212 and M4e cells treated with QN-Pt (II). " $P<0.05,{ }^{* *} p<0.01$, vs. control cells

QN-Pt (II) promoted autophagy and activated YAP in TU212 and M4e cells

As shown in Figure 4, treatment with QN-Pt (II) at doses of 4,6 and $10 \mu \mathrm{M}$ upregulated the expressions of LC3-II in TU212 and M4e cells in a concentration-dependent manner. The elevation of LC3-II expression was maximum in TU212 and M4e cells on treatment with $10 \mu \mathrm{M}$ QN-Pt (II) for $48 \mathrm{~h}$. In contrast, treatment with QN-Pt (II) increased P62 degradation in TU212 and $\mathrm{M} 4 \mathrm{e}$ cells in a concentration-based manner. The P62 degradation was markedly higher inTU212 and M4e cells treated with 4, 6 and 10 $\mu \mathrm{M}$ QN-Pt (II) for $48 \mathrm{~h}$. Total YAP expressions in TU212 and M4e cells were suppressed on treatment with 4, 6 and $10 \mu \mathrm{M}$ QN-Pt (II). However, p-YAP levels were markedly enhanced in both cell lines by QN-Pt (II) treatment.

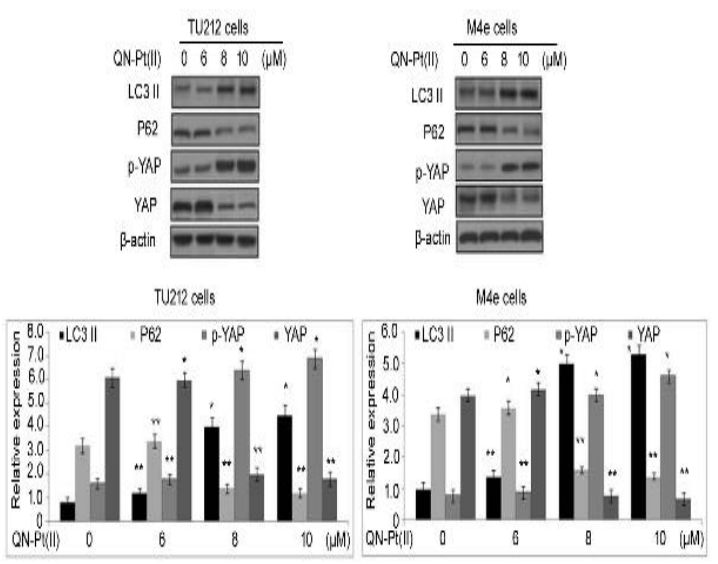

Figure 4: Effect of QN-Pt (II) on expressions of autophagy markers. The TU212 and M4e cells were treated with QN-Pt (II) at doses of 4, 6 and $10 \mu \mathrm{M}$ for $48 \mathrm{~h}$, followed by determination of the expression levels of LC3-II, p62, p-YAP and YAP with Western blotting; ${ }^{*} p<0.05,{ }^{* *} p<0.01$, vs. control cells. (YAP = yes-associated protein)

\section{YAP up-regulation antagonized Pt (II)-induced inhibition of cell proliferation}

Transfection of YAP-cDNA into TU212 and M4e cells reversed the inhibitory effect of QN-Pt (II) on cell proliferation (Figure $5 \mathrm{~A}$ ). The proliferations of TU212 and M4e cells were significantly increased by YAP-cDNA transfection. At a dose of $10 \mu \mathrm{M}, \mathrm{QN}-\mathrm{Pt}$ (II) decreased the proliferations of TU212 and M4e cells to 18 and $21 \%$, respectively, after $48 \mathrm{~h}$. However, transfection with YAP-cDNA increased the proliferation of QN-Pt (II)-treated TU212 and M4e cells to 98 and $99 \%$, respectively. This suggests that YAP-cDNA transfection reversed the inhibitory effect of QN-Pt (II) on the proliferative potential of TU212 and M4e cells. Moreover, YAP-cDNA transfection suppressed LC3II expression, inhibited YAP phosphorylation and promoted P62 expression in QN-Pt (II)treated TU212 and M4e cells (Figure $5 \mathrm{~B}$ ).

Trop J Pharm Res, August 2020; 19(8): 1628 


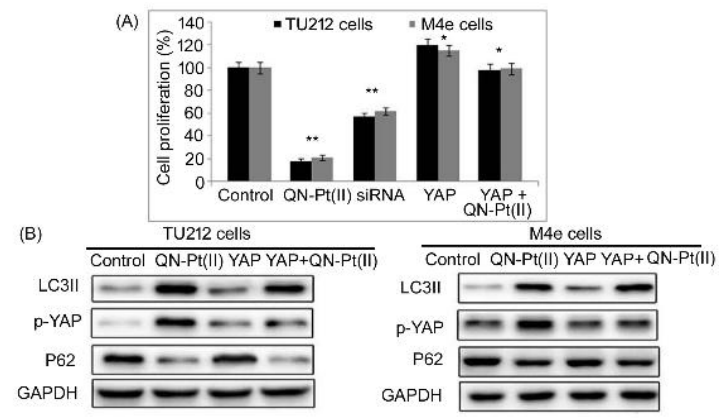

Figure 5: Effect of YAP-cDNA transfection on QN-Pt (II)-induced inhibition of cell growth. The TU212 and M4e cells transfected with YAP-cDNA were treated with $10 \mu \mathrm{MQN}-\mathrm{Pt}$ (II) for $48 \mathrm{~h}$. A: Changes in TU212 and $\mathrm{M} 4 \mathrm{e}$ cell proliferations, as measured using MTT assay. B: Changes in expressions of LC3II, p-YAP and P62, as assayed using Western blotting; ${ }^{*} p<0.05$, ${ }^{* *} p$ $<0.01$, vs. control cells

\section{DISCUSSION}

Platinum-containing drugs have been used extensively in anti-tumor chemotherapeutic strategies in the past few decades [13]. The use of a drug such as cisplatin is limited because of development of resistance and various harmful side effects in cells [14]. To eliminate this limitation, metal ion complexes are formed with organic compounds with potential anticancer properties [15]. Complexes derived from hydroxyquinoline and many metals have shown promising anti-cancer effects in vitro and in vivo [15]. The present study investigated the anticancer potential of quinolinol-platinum (II) complex [QN-Pt (II)] in TU212 and M4e laryngeal cancer cells. The results showed that QN-Pt (II) effectively inhibited cell growth in TU212 and M4e cell lines, without any effect on the viability of $\mathrm{HBe}$ normal cells. These preliminary data indicate the anti-cancer potential of QN-Pt (II) against TU212 and M4e laryngeal carcinoma cells. Moreover, QN-Pt (II) inhibited wound healing potential of TU212 and $\mathrm{M} 4 \mathrm{e}$ cells, and arrested their cell cycle at the G0/G1 phase, as was evident in increases in G1/G0 phase cell counts. It has been reported that autophagy is critical in inducing cell death, and is of importance in tumor growth [16]. The initiation of autophagy is characterized by cleavage of C-terminal LC3 to generate LC3II protein which is subsequently translocated into the autophagosomes [17]. Thus, LC3-II plays a vital role in the production of autophagosomes during autophagy [18].

Autophagy is accurately indicated by the degradation of p62 sequestosome [18]. In the present study, it was found that QN-Pt (II) promoted LC3-II expression and enhanced p62 degradation in TU212 and M4e cells. These findings suggest inhibitory effect of QN-Pt (II) on TU212 and M4e cells through induction of autophagy. A downstream factor of Hippo-YAP pathway, YAP is associated with inhibition of excessive proliferation of cells [19]

Suppression of YAP expression in cancer cells is associated with autophagy induction and cell differentiation [20]. In pulmonary and hepatic cancer cells, phosphorylation of YAP is important in the development of chemotherapeutic agents [21]. Therefore, YAP expression is considered a marker for development of effective treatment strategy for cancers [22]. It has been reported that phosphorylated YAP is unable to penetrate the nucleus, such that its activity is inhibited [23]. In the present study, QN-Pt (II) promoted YAP phosphorylation in TU212 and M4e cells. This suggests that QN-Pt (II) induces autophagy in TU212 and M4e cells via phosphorylation of YAP.

\section{CONCLUSION}

The results obtained in this study indicate that QN-Pt (II) effectively inhibits laryngeal carcinoma cell proliferation and migration, arrests cell cycle and activates autophagy. Moreover, QN-Pt (II) targets YAP expression, promotes expression of LC3-II and increases p62 degradation in laryngeal cancer cells. Therefore, QN-Pt (II) can potentially be used in the development of an effective and novel treatment for laryngeal cancer.

\section{DECLARATIONS}

\section{Conflict of interest}

No conflict of interest is associated with this work.

\section{Contribution of authors}

We declare that this work was done by the author(s) named in this article and all liabilities pertaining to claims relating to the content of this article will be borne by the authors. Tao Li conceived and designed the study; Baotong Xie and Tao $\mathrm{Li}-$ collected, analyzed the data and wrote the manuscript. Both the authors read and approved the manuscript for publication.

\section{Open Access}

This is an Open Access article that uses a funding model which does not charge readers or their institutions for access and distributed under 
the terms of the Creative Commons Attribution License (http://creativecommons.org/licenses/by/ 4.0) and the Budapest Open Access Initiative (http://www.budapestopenaccessinitiative.org/rea d), which permit unrestricted use, distribution, and reproduction in any medium, provided the original work is properly credited.

\section{REFERENCES}

1. Zhang $Y$, Chen $Y, Y u$ J, Liu G, Huang Z. Integrated transcriptome analysis reveals miRNA-mRNA crosstalk in laryngeal squamous cell carcinoma. Genomics 2014; 104: 249-256.

2. Hoffman HT, Porter K, Karnell LH, Cooper JS, Weber RS, Langer CJ, Ang KK, Gay G, Stewart A, Robinson $R A$. Laryngeal cancer in the United States: Changes in demographics, patterns of care, and survival. Laryngoscope 2006; 116: 1-13.

3. Ouyang D, LiU TR, Liu XW, Chen YF, Wang J, Su X, Yang AK. Combined hyoid bone flap in laryngeal reconstruction after extensive partial laryngectomy for laryngeal cancer. Eur Arch Otorhinolaryngol 2013; 270: 1455-1462.

4. Ulualp So. Mapping regional laryngopharyngeal mechanoreceptor response. Clin Exp Otorhinolaryngol 2014; 7: 319-323.

5. Zhang Sy, Iu ZM, Chen IS, luo $X N$, Ge PJ, Song $X H$, Chen SH, WU YL. Supracricoid partial laryngectomy cricohyoidoepiglottopexy (SCPL-CHEP) versus vertical partial laryngectomy for the treatment of glottic carcinoma. Eur Arch Otorhinolaryngol 2013; 270: 10271034.

6. Wang SP, Wang LH. Disease implication of hyper-Hippo signalling. Open Biol 2016; 6.

7. Wang Z, Liu $P$, Zhou $X$, Wang $T$, Feng $X$, Sun YP, Xiong $Y$, Yuan HX, Guan KL. Endothelin promotes colorectal tumorigenesis by activating YAP/TAZ. Cancer Res 2017; 77: 2413-2423.

8. Wang YP, Tang DX. Expression of Yes-associated protein in liver cancer and its correlation with clinicopathological features and prognosis of liver cancer patients. Int J Clin Exp Med 2015; 8: 1080-1086.

9. Medici S, Peana M, Nurchi VM, Lachowicz Jl, Crisponi G, Zoroddu MA. Noble metals in medicine: latest advances. Coord. Chem. Rev. 2015; 284: 329-350.

10. Monroe JD, Hruska HL, Ruggles HK, Williams KM, Smith1 ME. Anti-cancer characteristics and ototoxicity of platinum(II) amine complexes with only one leaving ligand. PLoS ONE 2018; 13: e0192505.
11. Chen ZF, Qin QP, Qin JL, Zhou J, Li YL, Li N, Liu YC, Liang $H$. Water-soluble ruthenium(II) complexes with chiral 4-(2, 3-dihydroxypropyl)-formamide oxoaporphine (FOA): in vitro and in vivo anticancer activity by stabilization of G-Quadruplex DNA, inhibition of telomerase activity, and induction of tumor cell apoptosis. J. Med. Chem. 2015; 58: 4771-4789.

12. Wang $Y$, Pang W, Zeng $Q$, Deng Z, Fan $T$, Jiang J, Deng $H$, Song D: Synthesis and biological evaluation of new berberine derivatives as cancer immunotherapy agents through targeting IDO1. Eur. J. Med. Chem. 2018; 143: 1858-1868.

13. Mou ZD, Deng N, Zhang F, Zhang JY, Cen J, Zhang X. "Half-sandwich" Schiff-base Ir(III) complexes as anticancer agents. Eur J Med Chem. 2017; 138: 72-82.

14. Geldmacher $Y$, Oleszak M, Sheldrick WS. Rhodium(III) and iridium(III) complexes as anticancer agents. Inorg Chim Acta 2012, 393, 84-102.

15. Guan R, Chen Y, Zeng L, Rees TW, Jin C, Huang J, Chen ZS, Ji LN, Chao H: Oncosis-inducing cyclometalated iridium(III) complexes. Chem Sci 2018; 9: $5183-5190$

16. Qian HR, Yang Y: Functional role of autophagy in gastric cancer. Oncotarget 2016; 7: 17641-17651.

17. Klionsky DJ, Abeliovich H, Agostinis $P$, Agrawal DK, Aliev G, Askew DS, Baba M, Baehrecke EH, Bahr BA, Ballabio $A$, et al. Guidelines for the use and interpretation of assays for monitoring autophagy in higher eukaryotes. Autophagy 2008; 4: 151-175.

18. Li YJ, Lei YH, Yao N, Wang CR, Hu N, Ye WC, Zhang $D M$, Chen ZS. Autophagy and multidrug resistance in cancer. Chin J Cancer 2017; 36: 52.

19. Wang $X$, Su L, Ou Q. Yes-associated protein promotes tumour development in luminal epithelial derived breast cancer. Eur J Cancer 2012; 48: 1227-1234.

20. Liu Z, Zeng W, Wang S, Zhao X, Guo Y, Yu P, Yin X, Liu C, Huang T. A potential role for the Hippo pathway protein, YAP, in controlling proliferation, cell cycle progression, and autophagy in BCPAP and $\mathrm{KI}$ thyroid papillary carcinoma cells. Am J Transl Res 2017; 9: 3212-3223.

21. Moroishi T, Hansen CG, Guan KL. The emerging roles of YAP and TAZ in cancer. Nat Rev Cancer 2015; 15: 7379.

22. Mo JS, Park HW, Guan KL: The Hippo signaling pathway in stem cell biology and cancer. EMBO Rep 2014; 15: 642-656.

23. Oku $Y$, Nishiya $N$, Shito $T$, Yamamoto $R$, Yamamoto $Y$, Oyama C, Uehara $Y$. Small molecules inhibiting the nuclear localization of YAP/TAZ for chemotherapeutics and chemosensitizers against breast cancers. FEBS Open Bio 2015; 5: 542-549.

Trop J Pharm Res, August 2020; 19(8): 1630 